JPPIPA, Vol.3 No.1 2018
Jurnal Penelitian Pendidikan IPA
htt/journal.unesa.ac.id/index.php/jppipa

\title{
PENGGUNAAN LEMBAR KERJA BERORIENTASI PENDEKATAN KETERAMPILAN PROSES UNTUK MELATIHKAN KETERAMPILAN PROSES SAINS SISWA SMP
}

Oleh:

Elok Sudibyo ${ }^{1}$, Tutut Nurita ${ }^{2}$, An Nuril Maulida Fauziah ${ }^{3}$

1,2,3 Jurusan IPA, Fakultas MIPA, Universitas Negeri Surabaya, Surabaya 60231, Indonesia.

\begin{abstract}
Abstrak
Penelitian ini bertujuan untuk mendeskripsikan keterampilan proses sains siswa SMP setelah menggunakan lembar kerja berorientasi pendekatan proses sains. Penelitian ini merupakan penelitian deskriptif yaitu penelitian yang mendeskripsikan hasil keterampilan proses sains yang dilatihkan pada siswa SMP Al Falah Ketintang Surabaya dan siswa SMP Al Falah Deltasari Sidoarjo dengan menggunakan Lembar Kerja yang berorientasi pendekatan keterampilan proses. Hasil penelitian menunjukkan bahwa keterampilan proses sains siswa mengalami peningkatan setelah menggunakan Lembar Kerja yang berorientasi pendekatan keterampilan proses.
\end{abstract}

Kata Kunci : lembar kerja siswa, keterampilan proses sains.

\begin{abstract}
This study aims to describe the science process skills of junior high school students after using a process-oriented work sheet approach to science. This research is a descriptive research that is research that describe the result of science process skill which is trained in junior high school student Al Falah Ketintang Surabaya and junior high school student Al Falah Deltasari Sidoarjo by using Student Worksheet oriented approach of science process. The results show that students' science process skills are improving by using Student Worksheet oriented approach of science process.
\end{abstract}

Keywords: student worksheet, science process skills.

(C) 2018 Universitas Negeri Surabaya

Alamat Korespondensi:

Jurusan IPA, Fakultas MIPA, Universitas

p-ISSN: $2527-7537$

Negeri Surabaya, Surabaya 60231, Indonesia

e-ISSN: 2549-2209

Email: eloksudibyo@unesa.ac.id 


\section{PENDAHULUAN}

Peraturan Menteri Pendidikan dan Kebudayaan no 58 tahun 2014 tentang kurikulum 2013 menyatakan bahwa: (1) Pembelajaran yang dilakukan guru dalam bentuk proses yang dikembangkan berupa kegiatan pembelajaran di sekolah, kelas, dan masyarakat dan (2) Pengalaman belajar langsung peserta didik sesuai dengan latar belakang, karakteristik, dan kemampuan awal peserta didik. Pengalaman belajar langsung individual peserta didik menjadi hasil belajar bagi dirinya, sedangkan hasil belajar seluruh peserta didik menjadi hasil kurikulum. Implementasi pendidikan di SMP selama ini lebih ditekankan pada pengetahuan, namun dengan diberlakukan kurikulum 2013 menjadikan kurikulum lebih menekankan pada proses pembangunan sikap, pengetahuan, dan keterampilan peserta didik melalui berbagai pendekatan yang mencerdaskan siswa. Penguasaan pada materi tidak lagi ditekankan pada pemahaman konsep melainkan pembangunan pengetahuan melalui pembelajaran otentik.

Sehubungan dengan itu, kurikulum 2013 lebih menerapkan pendekatan saintifik dalam pembelajaran dan penilaian otentik yang menggunakan prinsip penilaian bagian dari pembelajaran. Dengan memperkuat pendekatan ilmiah (scientific approach), yaitu terdiri dari 5M (mengamati, menanya, mengumpulkan informasi/mencoba, mengasosiasi, dan mengkomunikasikan). Menurut Collete dan Chiappetta (1994) dalam permendikbud No 58 Tahun 2014 disebutkan bahwa IPA pada hakikatnya merupakan kumpulan pengetahuan ( $a$ body of knowledge), cara atau jalan berpikir (method of thinking), dan cara untuk penyelidikan (method of investigating). Pendapat tersebut dapat diartikan bahwa IPA merupakan ilmu pengetahuan yang dapat dilakukan dengan berbagai macam yaitu berfikir dengan cara mengumpulkan informasi dan melakukan kegiatan dengan penyelidikan atau penemuan suatu masalah.

Lembar kerja IPA SMP yang beredar di lingkungan sekolah hanya berisi petunjuk praktikum, tabel pengamatan dan kesimpulan. Sehingga tidak melatihkan keterampilan proses, maka dari latar belakang di atas penelitian ini untuk menghasilkan Lembar Kerja IPA SMP berorientasi pendekatan keterampilan proses.

Pembelajaran sains yang baik adalah bila dilakukan seperti bagaimana sains itu ditemukan. Sains adalah karya manusia yang yang dihasilkan/ditemukan, yaitu melalui metode ilmiah dan menggunakan keterampilan proses sains. Metode ilmiah adalah metode untuk mendapatkan pengetahuan melalui jalur akal (nalar) dan jelur pengamatan. Wujud operasional metode ilmiah adalah penyelidikan ilmiah (Wahono, 2013).

Penyelidikan ilmiah didefinisikan sebagai usaha sistematik untuk mendapatkan jawaban atas masalah atau pertanyaan. Dengan demikian ciri khas metode ilmiah adalah pemecahan masalah melalui penalaran dan pengamatan. Jawaban pertanyaan dan atau penjelasan tentang masalah merupakan tubuh ilmu (sains) yang dipelajari oleh seseorang termasuk siswa. Oleh sebab itu pengajaran sains mengikuti alur penyelidikan ilmiah karena memiliki kualitas dan kuantitas hasil belajar yang lebih tinggi daripada hanya sekedar menghafal. Kualitas dapat diartikan sebagi tingkat pemahaman/retensi sedangkan kuantitas diatrikan sebagai jumlah hasil belajar yang dapat dicapai (Devi, 2010)

Faktor yang mempengaruhi pembelajaran yaitu faktor internal dan faktor eksternal. Faktor internal berupa kemampuan awal yang dimiliki siswa dan faktor eksternal berupa pendekatan pembelajaran. Pendekatan pembelajaran dapat dilaksanakan dengan menggunakan LKS. Lembar kerja siswa adalah sumber belajar siswa yang digunakan sebagai panduan untuk melakukan kegiatan penyelidikan atau pemecahan masalah.

Lembar kerja siswa (student worksheet) adalah lembaran-lembaran yang didalamnya berisi tugas yang dikerjakan oleh peserta didik. Lembar kerja berupa petunjuk, langkah-langkah yang digunakan untuk menyelesaikan suatu tugas (Depdiknas, 2008). Lembar kerja siswa dapat berupa pedoman yang digunakan untuk mengembangkan aspek kognitif maupun mengembangkan semua aspek pembelajaran dalam bentuk eksperimen pada kegiatan penyelidikan.

Prastowo (2011) mengatakan bahwa tugastugas dalam lembar kerja dapat berupa tugas teoritis dan tugas praktis. Lembar kerja siswa yang berisi tugas teoritis dapat berupa membuat ringkasan dan tugas praktis dapat berupa kerja laboratorium/ observasi lapangan. Lembar kerja berupa lembaran-lembaran yang berisi materi, ringkasan dan petunjuk pelaksanaan tugas yang akan dikerjakan oleh siswa, yang pembuatannya mengacu pada kompetensi dasar yang harus dicapai.

Berdasarkan beberapa pengertian yang telah disampaikan, maka dapat diambil kesimpulan bahwa lembar kerja siswa merupakan sumber belajar bagi siswa yang befungsi sebagai pedoman dalam melakukan kegiatan penyelidikan yang dapat mengembangkan berbagai aspek aspek pembelajaran. Penelitian dalam pengembangan lembar kerja IPA SMP ini dikembangkan dengan berorientasi pendekatan keterampilan proses. Kegiatan dalam Lembar Kerja berorientasi Pendekatan proses berisi mengidentifikasi masalah 
(merumuskan masalah), menentukan hipotesis, mengidentifikasi variabel, melakukan penyelidikan, dan melaporkan.

\section{METODE PENELITIAN}

Penelitian ini merupakan penelitian deskriptif, yaitu penelitian yang mendeskripsikan hasil penelitian secara kuantitatif disertai dengan penjelasan sesuai dengan teori yang diacu dalam penelitian. Instrumen yang digunakan pada penelitian ini adalah soal tes pretest dan posttest. Metode pengumpulan data yang digunakan adalah metode tes dilakukan untuk mengetahui peningkatan keterampilan proses sains siswa yang diukur menggunakan lembar soal pretest-posttet dengan menggunakan $N$-gain score Subyek penelitian yang digunakan adalah siswa SMP Al Falah Ketintang Surabaya dan siswa SMP Al Falah Deltasari Sidoarjo.

\section{HASIL DAN PEMBAHASAN}

Hasil analisis ketuntasan keterampilan proses sains siswa berdasarkan masing-masing komponen keterampilan proses sains siswa yang dilatihkan setelah menggunakan lembar kerja berorientasi pendekatan proses dapat dilihat dalam tabel berikut ini :

Tabel 1. Keterampilan Proses Sains Siswa Setiap Komponen

\begin{tabular}{clcc}
\hline No. & KPS yang dilatihkan & Pretest & Posttest \\
\hline 1 & Merumuskan Masalah & 6,125 & 83,500 \\
2 & Membuat Hipotesis & 4,750 & 88,375 \\
3 & Mengidentifikasi Variabel & 5,125 & 78,750 \\
4 & Menginterpretasi data & 26,520 & 87,090 \\
5 & Menarik Kesimpulan & 20,875 & 84,125 \\
6 & Mengkomunikasikan & 7,710 & 84,500 \\
\hline & Rata-rata & 11,85 & 84,39 \\
\hline
\end{tabular}

Peningkatan keterampilan proses sains siswa dengan menggunakan $N$-gain score, sebagai berikut.

Tabel 2. Peningkatan Keterampilan Proses Sains

\begin{tabular}{clcc}
\hline No. & \multicolumn{1}{c}{ KPS yang Dilatihkan } & N-gain & Kriteria \\
\hline 1 & Merumuskan Masalah & 0,82 & Tinggi \\
2 & Membuat Hipotesis & 0,88 & Tinggi \\
3 & Mengidentifikasi Variabel & 0,78 & Tinggi \\
4 & Menginterpretasi data & 0,82 & Tinggi \\
5 & Menarik Kesimpulan & 0,80 & Tinggi \\
6 & Mengomunikasikan & 0,83 & Tinggi \\
\hline
\end{tabular}

Keterampilan merumuskan masalah bertujuan untuk mengetahui dan memperjelas suatu masalah yang akan diselesaikan oleh siswa. Rumusan masalah yang baik memiliki ciri dirumuskan dalam bentuk kalimat tanya yang isinya padat dan jelas sehingga tidak menimbulkan penafsiran ganda serta dapat dijawab secara ilmiah.

Berdasarkan hasil pretest, nilai rata-rata keterampilan merumuskan masalah siswa adalah 6,125 dengan skor maksimal 100. Hal ini menunjukkan bahwa pengetahuan awal siswa terhadap keterampilan masalah masih sangat minim. Sesuai dengan penjelasan guru IPA melalui wawancara saat pra-penelitian di sekolah, bahwa siswa belum diajarkan mengenai keterampilan proses. Hal ini berarti siswa belum paham bagaimana membuat rumusan masalah yang baik dan benar. Setelah siswa memperoleh pembelajaran dengan menggunakan Lembar Kerja berorientasi Pendekatan Proses, hasil tes keterampilan merumuskan masalah mengalami kenaikan yang signifikan. Hal ini dibuktikan dengan rata-rata nilai posttest siswa sebesar 83,500. Berdasarkan Tabel 2 tentang peningkatan keterampilan proses sains siswa, diketahui adanya peningkatan antara nilai pretest-posttest untuk keterampilan merumuskan masalah dengan skor nGain sebesar 0,82 yang termasuk dalam kriteria tinggi.

Adanya peningkatan kemampuan siswa dalam merumuskan masalah ini karena melalui Lembar Kerja berorientasi Pendekatan Proses Siswa dilatihkan bagaimana membuat rumusan masalah yang baik dan benar. Pada Lembar Kerja 
berorientasi Pendekatan Ketermpilan Proses terdapat kegiatan yang dapat melatihkan siswa untuk aktif bertanya melalui bacaan yang tersedia. Kegiatan tersebut diharapkan dapat membuat siswa berlatih membuat pertanyaan ilmiah. Merumuskan masalah berarti bertanya secara ilmiah. Hal ini penting dilatihkan karena melalui bertanya, siswa tidak sekedar untuk memperoleh informasi melainkan untuk meningkatkan kemampuan berpikir siswa.

Hipotesis merupakan suatu dugaan yang merupakan jawaban terhadap suatu rumusan masalah sebelum dibuktikan kebenarannya. Berdasarkan hasil tes keterampilan proses sains pada kegiatan membuat hipotesis, rata-rata nilai pretest siswa hanya sebesar 4,750 dengan skor maksimal 100. Siswa dinyatakan tuntas jika nilai keterampilan proses sains mencapai batas KKM yang ditetapkan oleh sekolah yakni 70 (Kemendikbud, 2016). Dengan demikian nilai pretest siswa tersebut dinyatakan tidak tuntas. Penyebab rendahnya nilai siswa tersebut adalah siswa jarang dilatihkan cara membuat hipotesis selama pembelajaran IPA. Seperti pada keterampilan merumuskan masalah, melalui wawancara ketika pra-penelitian disekolah diketahui bahwa siswa belum diajarkan mengenai membuat hipotesis. Hal ini berarti siswa belum paham bagaimana membuat hipotesis yang baik dan benar. Menurut Ibrahim Muslimin dkk (2010), rumusan hipotesis berupa pernyataan yang di dalamnya harus terdapat variabel manipulasi dan variabel respon.

Setelah siswa memperoleh pembelajaran dengan menggunakan Lembar Kerja berorientasi Pendekatan Keterampilan Proses yang dikembangkan, hasil tes keterampilan membuat hipotesis mengalami peningkatan. Rata-rata nilai posttest siswa sebesar 88,375 dengan peningkatan skor n-Gain sebesar 0,88 yang termasuk dalam kriteria tinggi. Peningkatan tes keterampilan membuat hipotesis tersebut karena terdapat kegiatan pada Lembar Kerja berorientasi Pendekatan Keterampilan Proses yang berupa praktikum atau percobaan. Sesuai dengan pendapat Evanda (2015), kemampuan merumuskan hipotesis meningkat melalui kegiatan yang berbasis praktikum.

Siswa yang belum paham mengenai cara membuat hipotesis diberikan penjelasan terlebih dahulu mengenai cara membuat hipotesis yang benar melalui kegiatan yang ada pada Lembar Kerja berorientasi Pendekatan Keterampilan Proses.menyatakan bahwa anak pada usia SMP sudah dapat membuat hipotesis dari suatu masalah. Selain itu juga sebelumnya siswa telah dapat merumuskan masalah dengan peningkatan sebesar 0,82, maka siswa menjadi lebih mudah dalam membuat hipotesis karena rumusan masalah dan hipotesis merupakan dua hal yang saling berkaitan.

Variabel merupakan besaran yang dapat berubah nilainya pada kondisi tertentu (Nur, 2000). Variabel manipulasi merupakan variabel yang sengaja diubah. Faktor yang dapat berubah sebagai hasil variabel yang dimanipulasi disebut variabel respon. Sedangkan variabel yang dijaga kondisinya agar tetap sama dinamakan variabel kontrol (Nur, 2011).

Berdasarkan Tabel 1, hasil rata-rata nilai pretest siswa untuk keterampilan mengidentifikasi variabel hanya sebesar 5,125 dengan skor maksimal 100. Rendahnya keterampilan mengidentifikasi variabel ini dikarenakan siswa belum pernah dilatihkan keterampilan proses oleh guru, sehingga pengetahuan siswa terhadap keterampilan mengidentifikasi variabel masih sangat minim. Siswa belum mengerti bagaimana mengidentifasi variabel dengan benar. Selanjutnya, setelah memperoleh pembelajaran dengan menggunakan Lembar Kerja berorientasi Pendekatan Proses yang dikembangkan, hasil tes keterampilan mengidentifikasi variabel mengalami kenaikan. Hal ini terbukti dengan rata-rata nilai posttest siswa menjadi 78,750 dengan peningkatan antara nilai pretest-posttest berdasarkan analisis skor n-Gain sebesar 0,78 yang termasuk dalam kriteria tinggi.

Peningkatan nilai siswa pada posttest dikarenakan kegiatan Lembar Kerja berorientasi Pendekatan Keterampilan Proses yang di dalamnya sudah dicantumkan penjelasan dari tiap-tiap variabel percobaan. Siswa yang sebelumnya mampu membuat rumusan masalah dan hipotesis tentunya dapat mengetahui variabel manipulasi dan respon. Sesuai dengan Ibrahim Muslimin dkk (2014) bahwa hipotesis merupakan dugaan tentang pengaruh yang diberikan oeleh variabel manipulasi terhadap variabel respon. Sedangkan untuk mengetahui variabel kontrolnya, siswa dapat mengidentifikasi berdasarkan langkah percobaan.

Dibandingkan dengan keterampilan proses sains lain yang dilatihkan pada Lembar Kerja berorientasi Pendekatan Keterampilan Proses, keterampilan mengidentifikasi mendapatkan skor $\mathrm{n}$-Gain dengan kriteria tinggi. Hal ini dikarenakan beberapa siswa masih belum memahami cara mengidentikasi variabel yang benar. Meskipun dalam hal ini guru turut membimbing siswa dengan cara mengarahkan siswa terlebih dahulu untuk membaca langkah percobaan yang akan dilakukan, masih terdapat beberapa siswa yang kesulitan untuk membedakan variabel yang ada. Beberapa siswa masih banyak yang kesulitan membedakan antara variabel manipulasi, kontrol, maupun respon. Ini karena siswa masih asing dengan istilah-istilah tersebut. Sesuai dengan Ahmadi 
dalam Selva (2016) bahwa aktivitas belajar setiap individu, tidak selamanya dapat berlangsung secara wajar. Perbedaan antar individu ini menyebabkan perbedaan kemampuan siswa dalam menyerap pembelajaran berbeda satu sama lain. Maka, ada siswa yang mudah paham dalam sekali penjelasan, dan ada yang harus dijelaskan secara berulangulang untuk bisa memahami pembelajaran. Selain itu, aktivitas belajar seorang siswa dalam menangkap pembelajaran di kelas ada yang aktif maupun yang pasif.

Keterampilan menginterpretasi data merupakan keterampilan mencatat hasil pengamatan secara terpisah antara hasil utama dan hasil sampingan serta menghubungkan hasil dari pengamatan yang dilakukan. Berdasarkan Tabel 1. diketahui bahwa nilai rata-rata nilai pretest keterampilan menginterpretasi data siswa sebesar 26,520. Nilai ini merupakan yang paling tinggi dibandingkan dengan nilai keterampilan proses yang lain. Hal ini dikarenakan banyak siswa yang sudah paham mengenai cara menginterpretasi data. Meskipun demikian nilai tersebut masih masuk dalam kategori tuntas menurut Kemendikbud (2016), siswa dinyatakan tuntas jika nilai keterampilan proses sains yang dicapai sama dengan KKM. KKM yang ditetapkan oleh pihak sekolah adalah 70.

Selanjutnya, setelah siswa memperoleh pembelajaran dengan menggunakan Lembar Kerja berorientasi Pendekatan Keterampilan Proses telah dikembangkan, hasil tes keterampilan menginterpretasi data mengalami kenaikan. Hal ini dibuktikan dengan rata-rata nilai posttest siswa untuk keterampilan menginterpretasi data sebesar 87,090 dengan skor kenaikan n-Gain sebesar 0,82 dengan kriteria tinggi. Hasil ini merupakan yang tertinggi diantara 5 keterampilan proses yang lain. Jika dihubungkan dengan perolehan nilai pretest yang tinggi, maka nilai posttest yang mendekati nilai sempurna ini layak untuk didapatkan. Dengan pemahaman awal mengolah data yang cukup baik dari siswa ditambah dengan penggunaan Lembar Kerja berorintasi Pendekatan Keterampilan Proses yang terdapat kegiatan untuk melatihkan keterampilan menginterpretasi data dapat menjadikan siswa lebih mahir dalam mengaitkan data hasil percobaan dengan konsep-konsep yang ada. Sesuai dengan tingkat siswa SMP yang berada pada tingkat operasi formal sudah bisa untuk berpikir secara abstrak, memikirkan beberapa alternatif pemecahan masalah, mengembangkan hukum-hukum yang berlaku, dan pertimbangan ilmiah.

Menarik kesimpulan berarti memutuskan suatu peristiwa atau kejadian berdasarkan fakta, konsep, dan prinsip yang ditemukan melalui sebuah percobaan. Berdasarkan Tabel 1. diketahui bahwa nilai rata-rata nilai pretest keterampilan menarik kesimpulan sebesar 20,875. Setelah siswa memperoleh pembelajaran dengan menggunakan Lembar Kerja berorientasi Pendekatan Keterampilan Proses, hasil tes keterampilan menarik kesimpulan mengalami kenaikan yang dibuktikan dengan rata-rata nilai posttest siswa sebesar 84,125. Berdasarkan hasil tersebut, diketahui adanya peningkatan antara nilai pretestposttest dengan skor n-Gain sebesar 0,80 yang termasuk dalam kriteria tinggi.

Melalui Lembar Kerja berorientasi Pendekatan Keterampilan Proses siswa berlatih menarik kesimpulan melalui kolom kesimpulan yang disertai dengan kalimat pengantar untuk menggiring siswa menarik kesimpulan dengan baik dan benar. Hal ini dapat memudahkan siswa dalam berlatih keterampilan menarik kesimpulan. Peningkatan keterampilan menarik kesimpulan oleh siswa menunjukkan bahwa siswa telah mampu menarik suatu pernyataan berdasarkan fakta-fakta yang diketahui dari hasil pengamatan.

Keterampilan mengomunikasikan diartikan sebagai keterampilan menyampaikan hasil pengamatan secara lisan ataupun tulisan dalam suatu kegiatan diskusi berdasarkan fakta dan konsep yang disimpulkan. Mengomunikasikan dilakukan melalui penyampaian hasil kegiatan ilmiah yang telah dilakukan baik berupa tulisan, poster, multimedia dan sebagainya. Pada penelitian ini tes yang digunakan untuk mengetahui keterampilan mengomunikasikan siswa berupa menggambarkan ilustrasi atau gambar percobaan disertai dengan tabel data hasil percobaan disertai keterangan.

Berdasarkan tabel 1. diketahui bahwa nilai ratarata nilai pretest keterampilan mengomunikasikan sebesar 7,710. Hal ini sesuai dengan hasil test wawancara oleh salah satu guru IPA di dua sekolah SMP Al Falah Ketintang Surabaya dan SMP Al Falah Deltasari Sidoarjo, bahwa siswa belum diajarkan mengenai keterampilan proses sains, sehingga menyebabkan rendahnya hasil prestest siswa. Selanjutnya, setelah siswa memperoleh pembelajaran dengan menggunakan Lembar Kerja berorientasi Keterampilan Proses, hasil tes keterampilan mengomunikasikan mengalami kenaikan yang signifikan. Hal ini dibuktikan dengan rata-rata nilai posttest siswa sebesar 84,500. Berdasarkan hasil tersebut, diketahui adanya peningkatan antara nilai pretest-posttest dengan skor n-Gain sebesar 0,83 yang termasuk dalam kategori tinggi.

Peningkatan kemampuan mengomunikasikan data siswa tergolong peningkatan tertinggi kedua setelah keterampilan menginterpretasi data dibandingkan dengan peningkatan empat keterampilan proses yang lain. Adanya 
peningkatan tinggi dari keterampilan mengomunikasikan terbukti dapat dilatihkan melalui kegiatan yang ada di Lembar Kerja berorientasi Pendekatan Keterampilan Proses.

\section{PENUTUP}

\section{Simpulan}

Penggunaan Lembar Kerja berorientasi Pendekatan Keterampilan Proses untuk melatihkan keterampilan proses sains menunjukkan bahwa keterampilan proses sains siswa mengalami peningkatan rata-rata dengan kriteria tinggi.

\section{Saran}

Sebelum melaksanakan pembelajaran pastikan bahwa seluruh perangkat pembelajaran dan peralatan yang dibutuhkan telah disiapkan dengan baik agar pembelajaran terlaksana dengan baik.

\section{DAFTAR PUSTAKA}

Devi, Poppy Kamilia D. 2010. Keterampilan Proses dalam Pembelajaran IPA untuk Guru SMP. Jakarta: Pusat Pengembangan dan Pemberdayaan Pendidik dan Tenaga Kependidikan Ilmu Pengetahuan Alam (PPPPTIK IPA).

Dimyati dan Moedjiono. 2009. Belajar dan Pembelajaran.Jakarta: PT Rineka Cipta

Ibrahim, Muslimin. 2014. Inovasi Pendidikan Sains dalam Implementasi Kurikulum 2013. Makalah disampaikan pada Seminar Nasional Pendidikan Sains di PPs Universitas Negeri Surabaya tanggal 18 Januari 2014.

Kemendikbud. 2014. Peraturan Menteri Pendidikan dan Kebudayaan no 58 tahun 2014 tentang Panduan Kurikulum 2013.Jakarta: Badan Pengembangan Sumber Daya Manusia Pendidikan dan Kebudayaan dan Penjaminan Mutu.

Marno.2012. Bahan Ajar PLPG Pengembangan Bahan Ajar. Jakarta: Ditpais

Nur, Muhammad. 2011. Modul Keterampilanketerampilan Proses Sains. Surabaya: Universitas Negeri Surabaya Pusat Sains dan Matematika Sekolah (PSMS)

Nursalim, dkk 2007. Psikologi Pendidikan. Surabaya.: UNESA University Press.

Person Longman.2008. Scince Process Skills form 1. Selangon Malaysia

Prastowo, Andi. 2011. Panduan Kreatif Membuat Bahan Ajar Inovatif. Yogyakarta : Diva Press.

Wahono, Surya Ade dkk. 2013. Ilmu Pengetahuan Alam: Buku Guru/Kementrian Pendidikan dan Kebudayaan. Jakarta: Katalog Dalam Terbitan (KDT) 